agriTECH, 40 (3) 2020, 175-181

\title{
Aktivitas Antioksidan Bubuk Sargassum hystrix Selama Penyimpanan pada Suhu Berbeda
}

\author{
The Effect of Storage Temperature on Antioxidant Activity of Sargassum hystrix Powder \\ Pingkan Mayestika Afgatiani, Amir Husni*, Siti Ari Budhiyanti \\ Departemen Perikanan, Fakultas Pertanian, Universitas Gadjah Mada, Jl. Flora Gedung A4, Bulaksumur, \\ Yogyakarta 55281, Indonesia \\ *Penulis korespondensi: Amir Husni, E-mail: a-husni@ugm.ac.id
}

Tanggal submisi: 19 Januari 2017; Tanggal penerimaan: 7 Mei 2019

\begin{abstract}
ABSTRAK
Penelitian ini dilakukan untuk mengetahui pengaruh suhu penyimpanan terhadap aktivitas antioksidan bubuk Sargassum hystrix. Sampel berasal dari Pantai Sepanjang Gunung Kidul, Yogyakarta yang telah dikeringkan dan dibuat dalam bentuk bubuk kemudian diberikan perlakuan penyimpanan yaitu suhu kamar $\left(17-33^{\circ} \mathrm{C}\right)$, pendinginan $\left(4^{\circ} \mathrm{C}\right)$, dan pembekuan $\left(-18^{\circ} \mathrm{C}\right)$ selama 2 bulan dan selanjutnya diuji kadar air, total fenol, aktivitas antioksidan (DPPH dan FIC) setiap 2 minggu sekali, serta analisis senyawa menggunakan Gas ChromatographyMass Spectrometry (GC-MS) yang dilakukan sebelum dan setelah disimpan selama 2 bulan. Hasil penelitian menunjukkan bahwa kadar air semakin meningkat seiring dengan lama penyimpanan $(8,55-14,27 \%)$, sedang total fenol semakin menurun (175,73 mg GAE/g ekstrak menjadi terendah 4,73 mg GAE/g ekstrak). Hasil uji DPPH menunjukkan bahwa $S$. hystrix memiliki aktivitas antioksidan dengan nilai $\mathrm{IC}_{50} 0,45 \mathrm{mg} / \mathrm{mL}$ dan pada suhu pendinginan memiliki nilai $\mathrm{IC}_{50}$ terendah yaitu $3,18 \mathrm{mg} / \mathrm{mL}$. Pada pengujian FIC menunjukkan bahwa S. hystrix memiliki aktivitas antioksidan dengan nilai $\mathrm{IC}_{50} 1,44 \mathrm{mg} / \mathrm{mL}$ dan penyimpanan pada suhu pembekuan memiliki nilai $\mathrm{IC}_{50}$ terendah yaitu $15,36 \mathrm{mg} / \mathrm{mL}$. Hasil analisis GC-MS pada sampel sebelum dilakukan penyimpanan terdeteksi 8 senyawa yang memiliki aktivitas antioksidan, namun setelah disimpan selama 2 bulan, senyawa yang terdeteksi memiliki aktivitas antioksidan pada suhu kamar sebanyak 4 senyawa, pendinginan sebanyak 3 senyawa, dan pembekuan sebanyak 8 senyawa.
\end{abstract}

Kata kunci: Antioksidan; DPPH; FIC; suhu penyimpanan; Sargassum hystrix

\begin{abstract}
The aim of this study was to determine the effect of storage temperature on the antioxidant activity of Sargassum hystrix. Samples were collected from Sepanjang Beach Gunung Kidul, Yogyakarta, and dried, pulverized, and then stored for two months at room temperature $\left(17-33^{\circ} \mathrm{C}\right)$, refrigerator $\left(4^{\circ} \mathrm{C}\right)$ and freezer $\left(-18^{\circ} \mathrm{C}\right)$. Furthermore, the samples were tested every two weeks to determine their water content, total phenol, DPPH, and FIC. Also, Gas Chromatography-Mass Spectrometry (GC-MS) analysis was performed for two months before and after storage. The results showed that the water content increased after treatments, along with storage time which ranges from 8.55 to $14.27 \%$. Total phenol before storage was $175.73 \mathrm{mg} \mathrm{GAE} / \mathrm{g}$ extract, and freezing has the highest total phenol levels after storage which was $22.07 \mathrm{mg} \mathrm{GAE} / \mathrm{g}$ extract. Also, DPPH testing showed $S$. hystrix has an IC $_{50}$ value of $0.45 \mathrm{mg} / \mathrm{mL}$, and refrigeration has the lowest IC ${ }_{50}$ value of $3.18 \mathrm{mg} / \mathrm{mL}$. FIC test showed IC $\mathrm{IC}_{50}$ value of $1.44 \mathrm{mg} / \mathrm{mL}$, and freezing has the lowest FIC IC ${ }_{50}$ value of $15.36 \mathrm{mg} / \mathrm{mL}$. In addition, GC-MS sample analysis before storage detected 8 compounds with antioxidant activity of $86.96 \%$. After two months, they were detected at room temperature, refrigerator, and freezing which are 4, 3, and 8 compounds respectively.
\end{abstract}

Keywords: Antioxidant; DPPH; FIC; storage temperature; Sargassum hystrix

DOI: http://doi.org/10.22146/agritech.18134

ISSN 0216-0455 (Print), ISSN 2527-3825 (Online) 


\section{PENDAHULUAN}

Dewasa ini telah terjadi perubahan pola hidup dan pola makan di masyarakat sehingga mengakibatkan terjadinya berbagai kasus penyakit sebagai dampak dari terbentuknya radikal bebas yang berlebihan di dalam tubuh (Sen dkk., 2010). Senyawa radikal bebas merupakan salah satu penyebab kerusakan DNA dan juga dapat menyebabkan pemicu kerusakan saraf dan otak, peradangan, pengapuran tulang, gangguan pencernaan, gangguan hati, serta meningkatkan LDL (Khaira, 2010). Oleh sebab itu, tubuh kita memerlukan suatu substansi penting yakni antioksidan yang diharapkan dapat membantu melindungi tubuh dari serangan radikal bebas.

Sudah banyak penelitian mengenai alga sebagai sumber antioksidan. Salah satunya yaitu alga cokelat genus Sargassum. Penelitian mengenai antioksidan pada Sargassum telah banyak dilakukan seperti $S$. duplicatum (Septiana dan Asnani, 2013), S. polycycstum (Cahyaningrum dkk., 2016), S. cristaefolium (Lailiyah dkk., 2014), S. siliquastrum (Kim dkk., 2005), dan S. vulgare (Sarojini dkk., 2013). Penelitian Budhiyanti dkk. (2011) menunjukkan bahwa Sargassum hystrix dari Gunung Kidul memiliki aktivitas antioksidan tertinggi dari spesies lain.

Senyawa antioksidan pada rumput laut sangat sensitif terhadap suhu dan cahaya. Penelitian Husni dkk. (2014) menunjukkan bahwa aktivitas antioksidan Sargassumsp. cenderung menurun seiring meningkatnya suhu dan waktu pengeringan. Hal ini menunjukkan bahwa adanya pengaruh yang besar antara suhu dengan aktivitas senyawa antioksidan. Oleh sebab itu suhu penyimpanan perlu dikontrol dengan baik agar dapat menyimpan rumput laut dengan tetap mempertahankan aktivitas antioksidannya. Penelitian ini bertujuan untuk mengetahui pengaruh suhu penyimpanan terhadap aktivitas antioksidan $S$. hystrix, sehingga akan diketahui suhu yang sesuai untuk menyimpan bubuk $S$. hystrix.

\section{METODE PENELITIAN}

\section{Bahan}

Bahan utama yang digunakan yaitu S. hystrix dari Pantai Sepanjang Gunung Kidul dipanen pada bulan Januari 2016. Bahan yang lain meliputi etanol (MEDSIS), asam galat, $\mathrm{HCl}$ (Merck KGaA, USA), kertas Whatmann, Folin Ciocalteau, $\mathrm{Na}_{2} \mathrm{CO}_{3}$, DPPH, EDTA, $\mathrm{FeCl}_{2}$, asam askorbat (Merck KGaA, USA), ferozine (Aldrich, Jerman), dan akuabides.

\section{Alat}

Peralatan-peralatan yang digunakan dalam penelitian ini yaitu blender (Miyako, Jepang), stirrer, magnet stirrer, gunting, Erlenmeyer (Iwaki Pyrex, Jepang), evaporator, botol kaca, micropipette, 96-wellmicroplate, microtube (Eppendorf, Jerman), vortex, refrigerator (Sanyo, Jepang), freeze dryer (Lyovac GT 2, Jerman), GC-MS Shimadzu (Shimadzu, Jepang), dan freezer (Sanyo, Jepang).

\section{Preparasi Sampel}

Sampel S. hystrix dikeringanginkan hingga kering. Kemudian dipotong kecil-kecil kemudian diblender hingga menjadi bubuk. Sampel dalam bubuk dikemas menggunakan plastik PE dan disegel menggunakan sealer. Sebagian sampel diuji kadar air (BSN, 2006), total fenolat (Kang dkk., 2010), aktivitas antioksidan (Zubia dkk., 2009 dan Budhiyanti dkk., 2011) dan analisis senyawa menggunakan GC-MS, sedangkan sampel lain disimpan pada suhu kamar $\left(17-33^{\circ} \mathrm{C}\right)$, refrigerator (4 $\left.{ }^{\circ} \mathrm{C}\right)$, dan freezer $\left(-18,2{ }^{\circ} \mathrm{C}\right)$ selama 2 bulan dan diuji kadar total fenol, aktivitas antioksidan dan analisis senyawa setiap 2 minggu sekali

\section{Ekstraksi Polifenol}

Untuk mendapatkan ekstrak polifenol, ekstraksi rumput laut dilakukan menggunakan metode Kang dkk. (2010) yang dimodifikasi pelarutnya. Sampel kering diambil sebanyak $50 \mathrm{~g}$ dan dimasukkan ke dalam Erlenmeyer. Selanjutnya ditambahkan $486,68 \mathrm{~mL}$ etanol $96 \%$ dengan $\mathrm{pH} 4$ (diatur dengan penambahan $\mathrm{HCl} 1$ N) dan dilakukan pengadukan selama 3 jam. Setelah itu diendapkan selama 96 jam dan disaring dengan kertas Whatmann no 1 . Filtrat diambil dan diuapkan dengan rotary evaporator $\left(40-60{ }^{\circ} \mathrm{C}, 150 \mathrm{rpm}\right)$, lalu dikeringbekukan dan dihitung rendemennya.

\section{Analisis Kandungan Total Fenolat}

Kandungan total fenolat dianalisis menggunakan metode Kang dkk. (2010). Kurva standar dibuat dari asam galat dengan konsentrasi 6,$2 ; 12,5 ; 25 ; 50 ; 100$; $200 \mu \mathrm{g} / \mathrm{L}$. Sampel ekstrak diambil sebanyak $5 \mathrm{mg}$ dan dilarutkan dalam $1 \mathrm{~mL}$ etanol. Masing-masing larutan standard dan ekstrak diambil $10 \mu \mathrm{L}$ dan dimasukkan ke dalam microplate 96 well. Selanjutnya ditambahkan 50 $\mu \mathrm{L}$ Folin Ciocalteau dan diinkubasi 5 menit. Selanjutnya ditambahkan $40 \mu \mathrm{L} \mathrm{Na}_{2} \mathrm{CO}_{3}$ 7,5\% dan diinkubasi 2 jam di ruang gelap pada suhu ruang. Lalu ditera dengan ELISA reader pada panjang gelombang $750 \mathrm{~nm}$. 


\section{Aktivitas Antioksidan dengan Radical Schavenging Activity (RSA) DPPH}

Aktivitas antioksidan dengan metode RSA DPPH sebagaimana dijelaskan oleh Zubia dkk. (2009). Ekstrak dibuat variasi konsentrasi $1,2,3,4,5 \mathrm{mg} / \mathrm{mL}$ dan blanko berupa etanol. Selanjutnya, masing-masing konsentrasi diambil $22 \mu \mathrm{L}$ dan dimasukkan ke microplate. Larutan ditambahkan $200 \mu \mathrm{L}$ DPPH (25 mg/L) dan diinkubasi 2 jam diruang gelap pada suhu ruang dan ditera menggunakan ELISA reader pada panjang gelombang $515 \mathrm{~nm}$. Besarnya aktivitas antioksidan dihitung dengan Persamaan 1.

$$
\text { FIC }=\frac{1-(\text { abssampel }- \text { absblanko })}{\text { abskontrol }} \times 100 \%
$$

\section{Aktivitas Antioksidan dengan Ferrous Ion Chelating (FIC)}

Analisis aktivitas antioksidan dengan metode ini sebagaimana dijelaskan oleh Budhiyanti dkk. (2011). Ekstrak dibuat variasi konsentrasi 0,$125 ; 0,5 ; 1 ; 1,5 ; 2$ $\mathrm{mg} / \mathrm{mL}$. Masing-masing konsentrasi diambil $1 \mathrm{~mL}$ dan ditambah $\mathrm{FeCl}_{2} 2 \mathrm{mM}$ sebanyak 0,05 mL, ferozine $5 \mathrm{mM}$ sebanyak $0,2 \mathrm{~mL}$ dan akuabides sebanyak $2,75 \mathrm{~mL}$. Larutan diinkubasi 10 menit dalam ruang gelap pada suhu ruang dan ditera menggunakan spektrofotometer pada panjang gelombang $562 \mathrm{~nm}$. Blanko dibuat dari $\mathrm{FeCl}_{2}$ diganti dengan akuabides dan kontrol negatif dibuat dengan mengganti ekstrak menjadi akuabides. Aktivitas antioksidan dihitung dengan Persamaan 2.

$$
\mathrm{FIC}=\frac{1-(\text { abssampel }- \text { absblanko })}{\text { abskontrol }} \times 100 \%
$$

\section{Analisis Senyawa dengan GC-MS}

Analisis senyawa yang ada dalam eksktrak dilakukan dengan menggunakan GC-MS-QP2010S SHIMADZU, dilengkapi kolom AGILENT HP IMS dengan panjang 30 $\mathrm{m}$, ID $0,25 \mathrm{~mm}$, dan film 0,25 um serta flame thermionic detector (FTD). Sampel terlebih dahulu dilarutkan ke dalam pelarut organik sebanyak $50 \mu \mathrm{L}$. GC MS dilakukan dengan cara menyuntikan sampel sebanyak $10 \mu \mathrm{L}$ ke dalam kolom GC MS. Suhu saat injeksi adalah $70^{\circ} \mathrm{C}$ dan naik sebanyak $10^{\circ} \mathrm{C}$ tiap menit dengan suhu akhir 320 ${ }^{\circ} \mathrm{C}$. Gas helium $(99,99 \%)$ digunakan sebagai gas injeksi dengan kecepatan alir $1 \mathrm{~mL} / \mathrm{min}$.

\section{Analisis Data}

Data yang didapat akan diolah dengan analysis of variance (ANOVA) dengan tingkat kepercayaan 95\%. Jika hasil menunjukkan beda nyata, dilakukan uji lanjut menggunakan Duncan's Multiple Range Test (DMRT) untuk mengetahui beda nyata antar perlakuan (Gomez dan Gomez, 1984).

\section{HASIL DAN PEMBAHASAN}

\section{Rendemen}

Rendemen ekstrak yang dihasilkan selama penyimpanan pada 3 suhu penyimpanan dapat dilihat pada Tabel 1. Rendemen yang didapatkan pada ketiga perlakuan terlihat bahwa ketiganya mengalami penurunan seiring dengan bertambahnya waktu penyimpanan. Awal penyimpanan, sampel pada suhu kamar masih dapat mempertahankan rendemennya, namun seiring lama penyimpanan, suhu kamar memiliki rendemen terendah. Menurut Maulida dan Guntarti (2015), nilai rendemen yang tinggi menunjukkan proses ekstraksi senyawa aktif berlangsung efektif. Uji sidik ragam menunjukkan bahwa tidak ada pengaruh suhu dan waktu penyimpanan dengan rendemen yang dihasilkan. Penyimpanan pada minggu kedua hingga kedelapan menunjukkan bahwa tidak ada pengaruh antara suhu penyimpanan dengan rendemen ekstrak. Sedangkan uji statistik pada ketiga perlakuan selama penyimpanan terdapat beda nyata. Hal ini menunjukkan bahwa lama penyimpanan mempengaruhi rendemen yang dihasilkan. Rendemen yang semakin kecil menandakan bahwa terjadi degradasi pada senyawa aktif pada sampel (Pustiari dkk., 2014).

Tabel 1. Pengaruh suhu dan waktu penyimpanan terhadap rendemen bubuk $S$. hystrix

\begin{tabular}{llll}
\hline \multirow{2}{*}{$\begin{array}{l}\text { Minggu } \\
\text { ke- }\end{array}$} & \multicolumn{3}{c}{ Rendemen (\%) pada suhu } \\
\cline { 2 - 4 } & Kamar & Pendinginan & Pembekuan \\
\hline 0 & $3,28 \pm 0,3^{\mathrm{a}, \mathrm{z}}$ & $3,28 \pm 0,3^{\mathrm{a}, \mathrm{x}}$ & $3,28 \pm 0,3^{\mathrm{a}, y}$ \\
2 & $3,43 \pm 1,4^{\mathrm{a}, y}$ & $2,33 \pm 0,2^{\mathrm{a}, \mathrm{x}}$ & $2,06 \pm 0,3^{\mathrm{a}, x y}$ \\
4 & $3,05 \pm 0,2^{\mathrm{a}, y}$ & $2,03 \pm 0,2^{\mathrm{a}, \mathrm{x}}$ & $2,55 \pm 0,8^{\mathrm{a}, x y}$ \\
6 & $2,92 \pm 0,2^{\mathrm{a}, y}$ & $5,69 \pm 1,2^{\mathrm{a}, y}$ & $2,60 \pm 0,2^{\mathrm{a}, x y}$ \\
8 & $1,19 \pm 0,2^{\mathrm{a}, \mathrm{x}}$ & $1,64 \pm 0,1^{\mathrm{a}, \mathrm{x}}$ & $1,38 \pm 0,2^{\mathrm{a}, \mathrm{x}}$ \\
\hline
\end{tabular}

Keterangan: setiap nilai yang diikuti huruf yang sama dalam satu baris $(\mathrm{a}, \mathrm{b}, \mathrm{c})$ dan kolom $(\mathrm{x}, \mathrm{y}, \mathrm{z})$ menujukkan tidak beda nyata $(\mathrm{a}=$ $0,05)$

\section{Kadar Air}

Hasil pengukuran kadar air selama penyimpanan pada ketiga suhu penyimpanan dapat dilihat pada Tabel 2. Kadar air S. hystrix kering didapatkan sebesar $15,22 \%$. Namun, kadar air yang dihasilkan masih lebih tinggi daripada S. polycystum yaitu 2,05\% (Cahyaningrum dkk., 2016) dan lebih rendah dari Padina sp. yaitu 21,80\% (Husni dkk., 2014). Hasil uji 
Tabel 2. Pengaruh suhu dan waktu penyimpanan terhadap kadar air bubuk S. hystrix

\begin{tabular}{cccc}
\hline \multirow{2}{*}{$\begin{array}{c}\text { Minggu } \\
\text { ke- }\end{array}$} & \multicolumn{3}{c}{ Kadar air (\%) pada suhu } \\
\cline { 2 - 4 } & Kamar & Pendinginan & Pembekuan \\
\hline 0 & $8,54 \pm 0,4^{\mathrm{a}, \mathrm{w}}$ & $8,54 \pm 0,4^{\mathrm{a}, \mathrm{x}}$ & $8,54 \pm 0,4^{\mathrm{a}, \mathrm{x}}$ \\
2 & $16,18 \pm 0,3^{\mathrm{b}, \mathrm{z}}$ & $11,52 \pm 0,4^{\mathrm{a}, \mathrm{y}}$ & $16,38 \pm 1,1^{\mathrm{b}, \mathrm{z}}$ \\
4 & $13,80 \pm 1,8^{\mathrm{b}, \mathrm{x}}$ & $7,53 \pm 0,4^{\mathrm{a}, \mathrm{x}}$ & $12,80 \pm 1,3^{\mathrm{b}, \mathrm{y}}$ \\
6 & $15,02 \pm 0,7^{\mathrm{c}, y z}$ & $8,8 \pm 1,4^{\mathrm{a}, \mathrm{x}}$ & $12,63 \pm 0,7^{\mathrm{b}, \mathrm{y}}$ \\
8 & $14,27 \pm 0,8^{\mathrm{c}, \mathrm{xy}}$ & $8,55 \pm 0,1^{\mathrm{a}, \mathrm{x}}$ & $13,10 \pm 0,5^{\mathrm{b}, \mathrm{y}}$ \\
\hline
\end{tabular}

Keterangan: setiap nilai yang diikuti huruf yang sama dalam satu baris $(a, b, c)$ dan kolom $(w, x, y, z)$ menujukkan tidak beda nyata $(a=0,05)$

sidik ragam dan pengujian DMRT terlihat bahwa suhu dan waktu penyimpanan memberikan pengaruh pada kadar air sampel bubuk. Hal ini diduga karena pada suhu kamar terjadi proses transpirasi dan penyerapan air di udara oleh sampel dan kenaikan suhu dari tempat penyimpanan menuju tempat analisis kadar air pun cenderung akan memberikan pengaruh berupa penyerapan air, sehingga kadar air meningkat (Asgar dan Rahayu, 2014).

\section{Kadar Total Fenolat}

Kandungan total fenolat yang terdapat dalam ekstrak dapat dilihat pada Tabel 3. Berdasarkan hasil pengujian, dapat diketahui bahwa semakin lama waktu penyimpanan, total fenolat yang terkandung pun menurun. Penurunan yang terjadi yaitu sebesar 170,27 mg GAE/g ekstrak dari sebelum disimpan hingga penyimpanan minggu kedelapan pada suhu kamar, sedangkan pada suhu pendinginan hanya sebesar $162,63 \mathrm{mg} \mathrm{GAE} / \mathrm{g}$ ekstrak dan suhu pembekuan sebesar

Tabel 3. Pengaruh suhu dan waktu penyimpanan terhadap kadar total fenolat (mg GAE/g ekstrak) bubuk $S$. hystrix selama penyimpanan 2 bulan

\begin{tabular}{|c|c|c|c|}
\hline \multirow{2}{*}{$\begin{array}{c}\text { Minggu } \\
\text { ke- }\end{array}$} & \multicolumn{3}{|c|}{ Suhu } \\
\hline & Kamar & Pendinginan & Pembekuan \\
\hline 0 & $175,73 \pm 20,4^{a, z}$ & $175,73 \pm 20,4^{a, z}$ & $175,73 \pm 20,4^{a, z}$ \\
\hline 2 & $62,40 \pm 6,9^{a, y}$ & $78,73 \pm 0,6^{a, y}$ & $108,00 \pm 22,2^{a, y}$ \\
\hline 4 & $24,20 \pm 3,6^{a, x}$ & $54,40 \pm 0,4^{a, x}$ & $49,70 \pm 4,7^{a, x}$ \\
\hline 6 & $9,80 \pm 6,4^{a, x}$ & $29,13 \pm 9,3^{a, x}$ & $22,07 \pm 0,1^{\mathrm{a}, \mathrm{x}}$ \\
\hline 8 & $4,73 \pm 3,7^{a, x}$ & $13,10 \pm 5,4^{a, x}$ & $22,07 \pm 2,5^{b, x}$ \\
\hline
\end{tabular}

Keterangan: setiap nilai yang diikuti huruf yang sama dalam satu baris $(a, b, c)$ dan kolom $(x, y, z)$ menujukkan tidak beda nyata $(a=$ $0,05)$
151,66 mg GAE/g ekstrak. Hal tersebut berlaku pada ketiga suhu penyimpanan yang digunakan. Pengujian sidik ragam dan DMRT menunjukkan bahwa suhu dan waktu penyimpanan memberikan pengaruh pada kadar total fenolat.

Penelitian Reblova (2012) menyebutkan bahwa kenaikan suhu dapat mempengaruhi kadar fenolat dalam bahan. Semakin tinggi suhu penyimpanan, kadar fenolat semakin rendah. Suhu kamar memiliki suhu tertinggi daripada suhu penyimpanan lain (pendinginan dan pembekuan). Penelitian yang dilakukan oleh Nurhayati dkk. (2012) menunjukkan bahwa penyimpanan dapat menyebabkan perubahan pada fenolat sampel. Penyimpanan dengan suhu pembekuan (freezer) memiliki kandungan total fenolat tertinggi sampai penyimpanan minggu kedelapan. Penelitian Zavala dkk. (2004) pun menyatakan bahwa penyimpanan strawberi pada suhu pembekuan $\left(0^{\circ} \mathrm{C}\right)$ dapat mempertahankan kandungan senyawa fenolat sampai penyimpanan 13 hari. Penelitian Monica dkk. (2009) menjelaskan bahwa suhu yang tinggi akan merusak ikatan pada senyawa antioksidan (chain-breaking activity) sehingga aktivitas antioksidan menjadi menurun akibat ketidakstabilan dalam senyawa.

\section{Analisis Aktivitas Antioksidan}

\section{Uji DPPH}

Pengujian antioksidan dengan metode DPPH merupakan metode yang paling sering digunakan untuk mengetahui aktivitas antioksidan pada suatu sampel. Parameter untuk menginterpretasikan hasil pengujian DPPH adalah dengan $\mathrm{IC}_{50} . \mathrm{IC}_{50}$ merupakan konsentrasi larutan substrat atau sampel yang akan menyebabkan reduksi terhadap aktivitas DPPH sebesar 50 \%. Semakin kecil nilai $\mathrm{IC}_{50}$ berarti semakin tinggi aktivitas antioksidan (Molyneux, 2004). Hasil perhitungan $\mathrm{IC}_{50}$ dapat dilihat pada Tabel 4.

Hasil perhitungan $\mathrm{IC}_{50}$ didapatkan bahwa terjadi peningkatan nilai $\mathrm{IC}_{50}$ pada semua perlakuan suhu penyimpanan seiring dengan lama waktu penyimpanan. Pengujian sidik ragam dan DMRT menunjukkan bahwa suhu dan waktu penyimpanan memberikan pengaruh pada nilai $\mathrm{IC}_{50}$ sampel. Analisis statistika pada ketiga penyimpanan terdapat beda nyata pada setiap 2 minggu pengecekan. Namun, ketiga suhu penyimpanan tidak berbeda nyata sampai penyimpanan minggu keenam. Hal ini menunjukkan bahwa lama penyimpanan pada ketiga suhu penyimpanan selama enam minggu tidak memberikan pengaruh pada aktivitas antioksidan. Setelah disimpan hingga minggu kedelapan, terlihat bahwa adanya beda nyata atau aktivitas antioksidan mengalami penurunan. Hal ini sejalan dengan penelitian 
Tabel 4. Pengaruh suhu dan waktu penyimpanan terhadap nilai $\mathrm{IC}_{50}$ RSA DPPH $(\mathrm{mg} / \mathrm{mL})$ bubuk S. hystrix selama penyimpanan 2 bulan

\begin{tabular}{rcrr}
\hline \multirow{2}{*}{$\begin{array}{c}\text { Minggu } \\
\text { ke- }\end{array}$} & \multicolumn{3}{c}{ Suhu } \\
\cline { 2 - 4 } & \multicolumn{1}{c}{ Kamar } & Pendinginan & Pembekuan \\
\hline 0 & $0,45 \pm 0,3^{\mathrm{b}, y}$ & $0,45 \pm 0,3^{\mathrm{b}, \mathrm{x} y z}$ & $0,45 \pm 0,3^{\mathrm{b}, \mathrm{x} y}$ \\
2 & $0,75 \pm 0,2^{\mathrm{a}, x y}$ & $0,45 \pm 0,0^{\mathrm{b}, x y}$ & $0,99 \pm 0,0^{\mathrm{ab}, \mathrm{x}}$ \\
4 & $1,96 \pm 0,9^{\mathrm{b}, y}$ & $1,87 \pm 0,1^{\mathrm{a}, \mathrm{x}}$ & $1,76 \pm 0,3^{\mathrm{a}, y}$ \\
6 & $3,49 \pm 0,1^{\mathrm{b}, \mathrm{x}}$ & $1,98 \pm 0,5^{\mathrm{b}, \mathrm{z}}$ & $2,47 \pm 0,2^{\mathrm{a}, \mathrm{z}}$ \\
8 & $4,34 \pm 0,9^{\mathrm{b}, y z}$ & $3,18 \pm 0,2^{\mathrm{a}, y z}$ & $4,65 \pm 0,23^{\mathrm{b}, z}$ \\
\hline
\end{tabular}

Keterangan: setiap nilai yang diikuti huruf yang sama dalam satu baris $(a, b, c)$ dan kolom $(x, y, z)$ menujukkan tidak beda nyata $(a=$ $0,05)$

Cuong dkk. (2015) mengenai lama penyimpanan 6 spesies Sargassum dari Nhatrang Bay, Vietnam bahwa semakin lama waktu penyimpanan, maka aktivitas antioksidannya semakin menurun. Penelitian Juniarka dkk. (2011) pun menunjukkan bahwa adanya penurunan aktivitas antioksidan pada ekstrak rosella yang disimpan pada suhu $0-5^{\circ} \mathrm{C}$ selama 30 hari. Penelitian Monica dkk. (2009) menjelaskan bahwa kerusakan antioksidan akibat suhu tinggi yaitu suhu yang tinggi akan merusak ikatan pada senyawa antioksidan (chain-breaking activity) sehingga senyawa antioksidan menjadi menurun akibat ketidakstabilan dalam senyawa.

Hubungan TPC dengan nilai $\mathrm{IC}_{50}$ RSA DPPH dapat dilihat pada Gambar 1. Koefisien determinasi $\left(R^{2}\right)$ terlihat memiliki nilai sebesar $0,77-0,97$, yang berarti bahwa kadar fenolik memiliki pengaruh pada aktivitas antioksidan DPPH sebesar 77,20 - 96,50\%. Korelasi

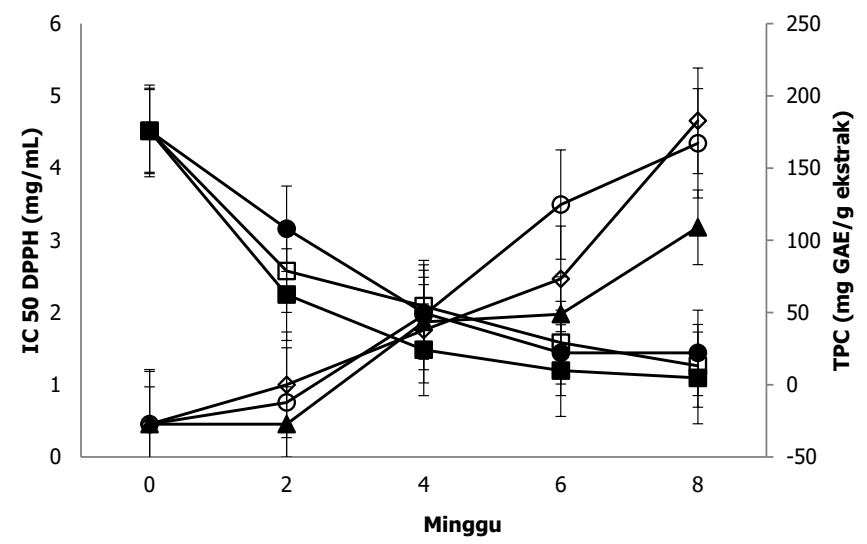

Gambar 1. Kurva hubungan antara kadar total fenolat ( $\mathbf{m}$ : suhu kamar; $\square$ : suhu pendinginan; $\bullet$ : suhu pembekuan) dengan aktivitas antioksidan $\left(\mathrm{IC}_{50} \mathrm{RSA}\right.$ DPPH $=0$ : suhu kamar; $\boldsymbol{\Delta}$ : suhu pendinginan; $\diamond$ : suhu pembekuan) bubuk Sargassum hystrix selama penyimpanan antara kadar total fenol dengan aktivitas antioksidan DPPH $(p<0,05)$ didapatkan bahwa kadar total fenol dengan aktivitas antioksidan DPPH memiliki korelasi yang signifikan, nilai korelasi $(R)$ sebesar $0,79-0,81$. Nilai korelasi (R) semakin mendekati 1 , maka hubungan antara kedua faktor semakin erat. Hal ini menunjukkan bahwa total fenol mempengaruhi aktivitas antioksidan DPPH dengan korelasi antar keduanya yang kuat.

\section{Uji Ferrous Ion Chelating (FIC)}

Salah satu mekanisme antioksidatif yaitu pengkelatan logam. Beberapa senyawa pada bahan alami mengandung flavonoid dan fenol yang memiliki kemampuan untuk mengkelat logam $\mathrm{Fe}^{+}$(Ebrahumzadeh dkk., 2008). Parameter untuk menginterpretasikan hasil pengujian FIC adalah dengan $\mathrm{IC}_{50}$. Nilai $\mathrm{IC}_{50}$ pada setiap perlakuan dapat dilihat pada Tabel 5.

Berdasarkan hasil pengujian FIC didapat bahwa nilai $\mathrm{IC}_{50}$ meningkat seiring dengan lama penyimpanan dan hal tersebut terjadi pada ketiga perlakuan suhu penyimpanan. Penyimpanan suhu kamar memiliki nilai IC $_{50}$ yang tinggi hingga penyimpanan minggu kedelapan. Hasil analisis sidik ragam dan DMRT menunjukkan bahwa adanya pengaruh suhu dan waktu penyimpanan terhadap nilai $\mathrm{IC}_{50}$ FIC. Analisis statistika pada ketiga penyimpanan terdapat beda nyata pada setiap 2 minggu pengecekan. Namun, pada minggu kedelapan tidak ada beda nyata antar suhu penyimpanan. Analisis statistika pada aktivitas pengkelatan logam pada masing-masing suhu penyimpanan berbeda nyata dengan lama penyimpanan. Hal ini menunjukkan bahwa aktivitas antioksidan akan berubah seiring dengan lamanya penyimpanan. Suhu tinggi dapat merusak kestabilan antioksidan, sehingga akan menghambat proses pengkelatan logam.

Tabel 5. Pengaruh suhu dan waktu penyimpanan terhadap aktivitas antioksidan (IC ${ }_{50}$ FIC, $\mathrm{mg} /$ $\mathrm{mL}$ ) bubuk $S$. hystrix selama penyimpanan 2 bulan

\begin{tabular}{crrr}
\hline \multirow{2}{*}{$\begin{array}{c}\text { Minggu } \\
\text { ke- }\end{array}$} & \multicolumn{3}{c}{ Suhu } \\
\cline { 2 - 4 } & \multicolumn{1}{c}{ Kamar } & \multicolumn{1}{c}{ Pendinginan } & \multicolumn{1}{c}{ Pembekuan } \\
\hline 0 & $1,44 \pm 0,2^{\mathrm{a}, \mathrm{x}}$ & $1,44 \pm 0,2^{\mathrm{a}, \mathrm{w}}$ & $1,44 \pm 0,2^{\mathrm{a}, \mathrm{x}}$ \\
2 & $2,42 \pm 0,6^{\mathrm{a}, \mathrm{x}}$ & $2,04 \pm 0,8^{\mathrm{a}, \mathrm{wx}}$ & $2,88 \pm 0,2^{\mathrm{b}, \mathrm{y}}$ \\
4 & $2,19 \pm 1,8^{\mathrm{c}, \mathrm{x}}$ & $2,5 \pm 0,07^{\mathrm{b}, \mathrm{x}}$ & $1,02 \pm 0,4^{\mathrm{a}, \mathrm{w}}$ \\
6 & $5,13 \pm 0,4^{\mathrm{b}, \mathrm{x}}$ & $19,8 \pm 0,34^{\mathrm{b}, \mathrm{z}}$ & $3,58 \pm 0,9^{\mathrm{b}, \mathrm{x}}$ \\
8 & $30,33 \pm 3,6^{\mathrm{a}, \mathrm{y}}$ & $20,56 \pm 0,9^{\mathrm{a}, \mathrm{y}}$ & $15,36 \pm 2,6^{\mathrm{a}, \mathrm{w}}$ \\
\hline
\end{tabular}

Keterangan: setiap nilai yang diikuti huruf yang sama dalam satu baris $(a, b, c)$ dan kolom $(w, x, y, z)$ menujukkan tidak beda nyata $(a=0,05)$ 


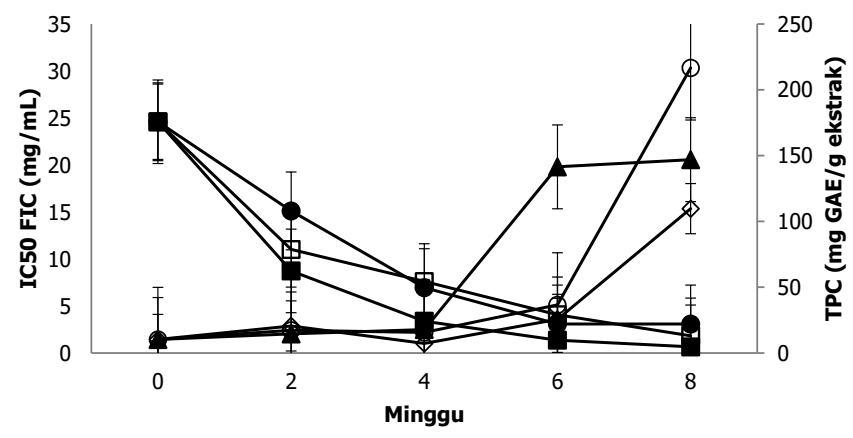

Gambar 2. Kurva hubungan antara kadar total fenolat (a: suhu kamar; $\square$ : suhu pendinginan; $\bullet$ : suhu pembekuan) dengan aktivitas antioksidan $\left(\mathrm{IC}_{50} \mathrm{FIC}=0\right.$ : suhu kamar; $\boldsymbol{\Delta}$ : suhu pendinginan; $\diamond$ : suhu pembekuan) bubuk Sargassum hystrix selama penyimpanan

Ebrahimzadeh dkk. (2008) mengatakan bahwa kemampuan pengkelatan logam memiliki korelasi langsung dengan komponen aktif seperti total fenol. Hal ini dapat terlihat pada Gambar 2. Koefisien determinasi $\left(R^{2}\right)$ terlihat memiliki nilai sebesar $0,57-0.88$, yang berarti bahwa kadar fenolat memiliki pengaruh pada aktivitas antioksidan FIC sebesar 57,202 - 88,40\%. dan sisanya dipengaruhi oleh senyawa lain. Korelasi antara kadar total fenolat dengan aktivitas antioksidan FIC $(p<0,05)$ didapatkan bahwa kadar total fenol dengan aktivitas antioksidan FIC memiliki korelasi yang signifikan, nilai korelasi $(R)$ sebesar 0,49-0,73. Nilai korelasi ( $R$ ) semakin mendekati 1 , maka hubungan antara kedua faktor semakin erat. Hal ini menunjukkan bahwa total fenol mempengaruhi aktivitas antioksidan FIC dengan korelasi antar keduanya yang kuat. Hossain dkk. (2014) juga menjelaskan bahwa senyawa fitokimia terutama senyawa fenolik seperti flavonoid, asam fenolat, dan tannin memiliki peran yang sangat penting dalam pengkelatan logam, seperti pada S. polycystum, S. duplicatum, dan S. cristaefolium.

\section{Analisis GC-MS}

Hasil analisis Gas Chromatography Mass Spectrometry (GC-MS) menunjukkan bahwa senyawa yang mempunyai aktivitas antioksidan pada ekstrak $S$. hystrix sebelum dilakukan penyimpanan terdapat 10 senyawa yaitu Hexadecanoic acid, Decanoic Acid, Palmitic acid, Dodecanoic acid, 9,12-Octadecadienoic acid, Tetradecanoic acid, Myristic acid, Octadecanoic acid, 9-Octadecenoic acid, dan Cis-13-Octadecenoic acid. Senyawa yang teridentifikasi dan mempunyai aktivitas antioksidan untuk penyimpanan suhu kamar adalah Hexadecanoic acid, Tridecanoic acid, vitamin $\mathrm{E}$ dan Ethyl oleate. sedang untuk penyimpanan suhu pendinginan yaitu Oxirane, Octadecanoid acid,
Hexadecanoic acid dan Stigmast-5-en-3-ol. Kemudian senyawa yang teridentifikasi pada penyimpanan dengan suhu pembekuan dan mempunyai aktivitas antioksidan yaitu Hexadecanoic acid, Farnesol, Ergosta5,7,24(28)-trienol, Cholesta-4-dien-3-ol, Hexadecene, Vitamin E, Benzoic acid, dan 2-Hexyl-1-octanol. Hal ini menunjukkan bahwa penyimpanan pada suhu beku lebih baik dalam mempertahankankan aktivitas antioksidan dibanding suhu dingin maupun suhu kamar. Cao dkk. (2007) melaporkan bahwa penyimpanan suhu $1^{\circ} \mathrm{C}$ dapat mempertahankan aktivitas antioksidan lebih baik daripada suhu $20^{\circ} \mathrm{C}$.

\section{KESIMPULAN}

Suhu penyimpanan dapat mempengaruhi aktivitas antioksidan bubuk $S$. hystrix ditandai dengan nilai sebelum dan sesudah penyimpanan untuk total fenolat $175,73 \pm 20,40 \mathrm{mg}$ GAE$/ \mathrm{g}$ ekstrak menjadi 4,73 $\pm 3,70$ $-22,07 \pm 2,50 \mathrm{mg} \mathrm{GAE} / \mathrm{g}$ ekstrak, nilai IC $\mathrm{IC}_{50}$ RSA 0,45 \pm $0,25 \mathrm{mg} / \mathrm{mL}$ menjadi $3,18 \pm 0,20-4,65 \pm 0,23 \mathrm{mg} / \mathrm{mL}$, nilai IC I0 $_{5}$ FIC 1,44 $\pm 0,20$ menjadi 15,36 $\pm 2,60-30,33$ $\pm 3,60 \mathrm{mg} / \mathrm{mL}$. Dari analisis GC-MS diperoleh senyawa antioksidan sebelum disimpan sebanyak 10 senyawa dan setelah disimpan delapan minggu pada suhu kamar sebanyak 3 senyawa, suhu pendinginan sebanyak 4 senyawa, dan suhu pembekuan sebanyak 8 senyawa.

\section{UCAPAN TERIMA KASIH}

Penelitian ini dapat terlaksana berkat dukungan dana dari Direktorat Penelitian dan Pengabdian kepada Masyarakat Direktorat Jenderal Pendidikan Tinggi Kementerian Pendidikan dan Kebudayaan Republik Indonesia melalui skim Hibah Penelitian Unggulan Perguruan Tinggi yang diselenggarakan oleh Lembaga Penelitian dan Pengabdian kepada Masyarakat Universitas Gadjah Mada Tahun 2014 dengan Nomor: LPPM-UGM/430/LIT/2014, tanggal 3 Maret 2014.

\section{KONFLIK KEPENTINGAN}

Penulis menyatakan tidak ada konflik atau kepentingan dengan pihak lain.

\section{DAFTAR PUSTAKA}

Asgar, A., \& Rahayu, S.T. (2014). Pengaruh suhu penyimpanan dan waktu pengkondisian untuk mempertahankan kualitas kentang kultivar Margahayu. Berita Biologi, 13: 283-293. http://dx.doi.org/10.14203/beritabiologi. v13i3.672 
BSN (Badan Standarisasi Nasional). (2006). Cara Uji KimiaBagian 2: Penentuan Kadar Air pada Produk Perikanan. SNI-01-2354.2-2006. Standar Nasional Indonesia (SNI).

Budhiyanti, S.A., Raharjo, S., Marseno, D.W., dan Lelana, I.Y.B. (2011). Free radical scavenging, metal chelating, and singlet oxygen quenching activity of fractionated brown seaweed Sargassum hystrix extract. Journal of Biological Sciences, 3: 1-11. http://dx.doi.org/10.3923/ jbs.2011.288.298

Cahyaningrum, K., Husni, A., \& Budhiyanti, S.A. (2016). Aktivitas antioksidan ekstrak rumput laut cokelat (Sargassum polycystum). Agritech, 36: 137-144. https:// doi.org/10.22146/agritech.12857

Cao, S.F., Zheng, Y.H., Yang, Z.F., Li, N., Ma, S.J., Tang, S.S., \& Zhang, J.H. (2007). Effects of storage temperature on antioxidant composition and anti-oxidant activity of loquat fruit. Acta Horticulturae, 750: 471-47. DOI: 10.17660/ActaHortic.2007.750.75

Cuong, D.X., Boi, V.N., Van, T.R.T., \& Hau, L.N. (2015). Effect of storage time on phlorotannin content and antioxidant activity of six Sargassum species from Nathrang Bay, Vietnam. Journal of Application and Phycology, 2: 567572. https://doi.org/10.1007/s10811-015-0600-y

Ebrahimzadeh, M.A., Pourmorad, F., \& Bekhradnia, A.R. (2008). Iron chelating activity, phenol and flavonoid content of some medicinal plants. African Journal of Biotechnology, 7: 3188-3192. DOI: 10.3923/pjbs.2009.934.938

Gomez, K.A. \& Gomez A.A. (1984). Statistical Procedures for Agricultural Research. John Willey and Sons. Canada.

Hossain, M.D., Sarwar, M.S., Dewan, S.M.R., Hossain, M.S., Shahid-Ud-Daula, A.F.M. \& Islam, M.S. (2014). Investigation of total phenolic content and antioxidant activities of Azadirachta indica roots. Avicenna Journal of Phytomedicine, 4: 97-102.

Husni, A., Putra, D.R., \& Lelana, I.Y.B. (2014). Aktivitas antioksidan Padina sp. pada berbagai suhu dan lama pengeringan. Jurnal Pascapanen dan Bioteknologi Kelautan dan Perikanan, 9: 165-173. http://dx.doi. org/10.15578/jpbkp.v9i2.109

Juniarka, I.G.A., Lukitaningsih, E., \& Noegrohati, S. (2011). Analisis aktivitas antioksidan dan kandungan antosianin total ekstrak dan liposom kelopak bunga Rosella (Hibiscus sabdariffa L.). Majalah Obat Tradisional, 16: 115-123.

Kang, C., Jin, Y.B., Lee, H., Cha, M., Sohn, E., Moon, J., Park, C., Chun, S., Jung, E.S., Hong, J.S., Kim, S.B., Kim, J.S., \& Kim, E. (2010). Brown alga Ecklonia cava attenuates type 1 diabetes by activating AMPK and akt signaling pathways. Food and Chemical Toxicology, 48: 509-516. https://doi.org/10.1016/j.fct.2009.11.004

Khaira, K. (2010). Menangkal radikal bebas dengan antioksidan. Jurnal Saintek, 2: 183-187.

Kim, S., Woo, S., Yun, H., Yum, E., Choi, E., Do, J.R., Jo, J.H., Kim, D., Lee, S., \& Lee, T.K. (2005). Total phenolic contents and biological activities of Korean seaweed extracts. Food Science and Biotechnology, 14: 798-802

Lailiyah, A., Adi, T.K., Hakim, A., \&Yusnawan, E. (2014). Kapasitas antioksidan dan kandungan total senyawa fenolik ekstrak kasar alga coklat Sargassum cristaefolium dari Pantai Sumenep Madura. Alchemy, 3: 18-30. DOI: 10.18860/al.v0i0.2902

Maulida, R., \& Guntarti, A. (2015). Pengaruh ukuran partikel beras hitam (Oryza sativa L.) terhadap rendemen ekstrak dan kandungan total antosianin. Pharmaciana, 5: 9-6. http://dx.doi.org/10.12928/pharmaciana.v5i1.2281

Molyneux, P. (2004). The use of the stable free radical Diphenyl Picryl Hydrazyl (DPPH) for estimating antioxidant activity. Songklanakarin Journal of Science and Technology, 26: 211-219.

Monica, A., Madrau, Piscopo, A., Sanguetti, A.M., Caro, A.D., Poina, M., Romeo, F.V., \& Piga, A. (2009). Effect of drying temperature on polyphenolic content and antioxidant activity of Apricots. Europe Food Reseacrh Technology, 228: 441-448. DOI: 10.1007/s00217-008-0951-6

Nurhayati, Siadi, K., \& Harjono. (2012). Pengaruh konsentrasi Natrium Benzoat dan lama penyimpanan pada kadar fenolat total pasta tomat. Indonesian Journal of Chemical Science, 1: 159-163.

Pustiari, P.A., Leliqia, N.P.E., \& Wijayanti, N.P.A.D. (2014). Penentuan rendemen antosianin total ekstrak kulit buah Manggis (Garciania mangostana, L) dengan pengeringan oven. Jurnal Farmasi Udayana, 3: 9-12.

Reblova, Z. (2012). Effect of temperature on the antioxidant activity of phenolic acids. Czech Journal of Food Science, 30: 171-177. DOI: 10.17221/57/2011-CJFS

Sarojini, Y.B., Sujatha, \& Lakshinarayana, K. (2013). Total phenol content and antioxidant activities of ethanolic extracts of two marine brown macroalgae. International Journal of Current Science, 8: 4-49.

Sen, S., Raja, C., Sridhar, C., \& Reddy, Y.S.R. (2010). Free radicals, antioxidants, diseases and phytomedicines: Current status and future prospect. International Journal of Pharmaceutical Sciences, 3: 91-100.

Septiana, A.T., \& Asnani, A. (2013). Aktivitas antioksidan ekstrak rumput laut Sargassum duplicatum. Jurnal Teknologi Pertanian, 14: 79-86. https://jtp.ub.ac.id/ index.php/jtp/article/view/396/757

Zavala, J.F.A., Wang, S.Y., Wang, C.Y., \&Agular, G.A.G. (2004). Effect of storage temperatures on antioxidant capacity and aroma compounds in strawberry fruit. Lebensm.Wiss. U.-Technology, 37: 687-695. DOI: 10.1016/j. Iwt.2004.03.002

Zubia, M., Fabre, M.S., Kerjean, V., Lann, K.L., Stiger-Pouvreau, V., Fauchon, M., \& Deslandes, E. (2009). Antioxidant and antitumoural activities of some phaeophyta from Brittany coasts. Food Chemistry, 116: 693-701. https:// doi.org/10.1016/j.foodchem.2009.03.025 